\title{
PEMAHAMAN KARYAWAN PADA BUDAYA ORGANISASI DI PT. ABC MEDIUM DINAMIKA
}

\begin{abstract}
Abdul Kholik ${ }^{1}$
Abstract

PT ABC Medium which was originally a stand-alone medium agency company, but after the company was acquired by a multinational company engaged in the medium sector. Since PT. ABC Medium joined and became part of this company, PT. ABC Medium is undergoing changes both in the organizational structure, work procedures and other regulations, therefore it is necessary to transform the culture of the company so that the behavior of its employees can adjust to the company's vision of becoming a global player. This study aims to determine employee understanding of old cultural values and employee understanding of the company's new cultural values. The research approach used is qualitative, with a constructivism paradigm, and the type of study is a case study. The results revealed that employees understood the value of the company's old culture as a culture of family, leadership, relaxed, bureaucratic, less competitive, client oriented, competency based. Employees understand the new culture of the company as a culture that has discipline values, rewards and sacrifices, is efficient, based on competence, prioritizes education but lacks role models.
\end{abstract}

Keywords : communication, organization, corporate culture

\begin{abstract}
Abstrak
PT ABC Medium yang semula merupakan perusahaan agensi medium yang berdiri sendiri namun setelah perusahaan tersebut diakuisisi oleh salah satu perusahaan multinasional yang bergerak di bidang yang medium. Semenjak PT. ABC Medium bergabung dan menjadi bagian dari perusahaan ini, PT. ABC Medium mengalami perubahan baik secara struktur organisasi, prosedur kerja dan peraturan lainnya, untuk itu diperlukan upaya transformasi budaya perusahaan supaya perilaku karyawannya dapat menyesuaikan dengan visi perusahaan yakni menjadi pemain global. Penelitian ini bertujuan untuk mengetahui pemahaman karyawan mengenai nilai budaya lama dan pemahaman karyawan mengenai nilai budaya baru perusahaan. Pendekatan penelitian yang digunakan adalah kualitatif, dengan paradigma konstruktivisme, dan jenis studi adalah studi kasus. Hasil penelitian mengungkapkan bahwa karyawan memahami nilai budaya lama perusahaan sebagai budaya kekeluargaan, kepemimpinan, santai, birokrasi, kurang kompetitif, client oriented, berbasis kompetensi. Karyawan memahami budaya baru perusahaan sebagai budaya yang memiliki nilai disiplin, adanya ganjaran dan pengorbanan, efisien, berdasarkan kompetensi, mengutamakan pendidikan tetapi kurang adanya keteladanan.
\end{abstract}

Kata kunci: komunikasi, organisasi, budaya perusahaan.

\footnotetext{
${ }^{1}$ Alamat kini: Institut Bisnis dan Informatika Kwik Kian Gie, Jln Yos Sudarso Kav. 87 Sunter, Jakarta 14350. Penulis untuk korespodensi : Telp : (021) 65307062 Ext 705. E-mail : abdul.kholik@kwikkiangie.ac.id
} 


\section{PENDAHULUAN}

Secara umum, komunikasi merupakan proses penyampaian pesan dari seseorang kepada orang lain. Para pakar mengemukakan bahwa komunikasi sangat amat penting dalam menjalani proses kehidupan. Tidak hanya dalam kehidupan bersosial, dalam suatu perusahaan sekalipun proses komunikasi kedudukannya sangat penting. Suatu perusahaan akan berhasil jika para karyawannya memiliki manajemen komunikasi yang baik dan efektif. Komunikasi efektif ini digunakan untuk menyampaikan norma dan aturan serta nilai-nilai agar terjadi pemahaman yang sama. Dalam hal ini, karyawan merupakan bagian dari budaya perusahaan.

PT ABC Medium Dinamika adalah salah satu perusahaan yang menggeluti bidang agensi medium. Dalam hal ini, PT ABC melakukan pekerjaan seperti mengembangkan plan atau perencanaan medium dengan strategi taktis demi mencapai target yang disesuaikan dengan trend atau kebutuhan pasar, membuat kampanye untuk peluncuran suatu brand, meninjau penguaan medium secara efektif dan kreatif dengan tetap melihat keefisiensiannya.

Budaya organisasi atau budaya perusahaan berfungsi sebagai bentuk adaptasi dengan lingkungan baik internal maupun eksternal. Maka dari itu, suatu perusahaan dituntut dapat selalu beradaptasi dengan berbagai lingungan sehingga dapat melakukan transformasi budaya.

Setiap perusahaan pasti memiliki tantangan dalam proses kemajuannya, begitu pun PT ABC yang tidak luput dari tantangan, baik internal maupun eksternal. Tantangan eksternal misalnya tantangan dalam berbisnis. sedangkan tantangan internal datang dari karyawan perusahaan itu sendiri, di mana selalu diam di zona nyaman dengan merasa tidak memiliki saingan serta berada di lingkungan AURI. Hal itu selalu melekat meskipun tuntutan zaman sudah berubah, perilaku lama para karyawan masih terbawa sementara perusahaan bukan lagi sebagai perusahaan ynag monopoli. Dengan demikian nilai-nilai yang dianut sudah tidak sesuai dengan lingkungan dan tuntutan. Maka dari itu, transformasi budaya perusahaan sangat diperlukan untuk mengubah budaya perusahaan.

Berdasarkan hal tersebut, penulis tertarik untuk meneliti transformasi budaya perusahaan di PT ABC Medium Dinamika. Tujuan dari penelitian ini yaitu untuk memperoleh gambaran mengenai pemahaman karyawan terhadap nilai-nilai budaya baik yang lama maupun yang baru. Adapun permaalahan yang menjadi fokus dalam penelitian ini yaitu hal-hal yang berkenaan dengan situasi dan kondisi subjektif dari perilaku transformasi budaya perusahaan dalam hal ini yaitu pada para karyawan yang mengkonstruksi budaya perusahaan.

Penelitian ini tidak lepas dari berbagai perspektif teoritis. Tujuannya sebagai pedoman dan panduan bagi penulis dalam melakukan penelaahan serta menganalisis realitas yang ada. Dalam penelitian ini, tentu saja peneliti menguraikan teori-teori yang relevan untuk digunakan dalam menganalisis serta membahas berbagai temuan di lapangan. Berbagai teori tersebut misalnya, Teori Budaya Organisasi, Teori Konstruksi Sosial atas Realitas, dan Teori Interaksi Simbolik. Adapun tujun dari penelitian ini yaitu untuk mengetahui pemahaman para karyawan mengenai budaya lama dan budaya baru dalam perusahaan. Selain itu penelitian ini diharapkan dapat memberikan manfaat dan kontribusi kepada PT ABC Medium Dinamika sehingga dapat mengimplementasikan budaya baru yang dapat mendukung perubahan dalam perusahaan.

\section{LANDASAN KONSEPTUAL}

Komunikasi Organisasi

Organisasi dapat dipandang dari dua pendekatan yaitu pendekatan objektif dan pendekatan subjektif, tergantung cara pandang kita. Pendekatan objektif mengatakan bahwa organisasi adalah sesuatu yang bersifat fisik dan konkret, dan merupakan sebuah struktur dengan batasbatas yang pasti yang merangkum orangorang, hubungan-hubungan, tujuantujuan, dan menganggap organisasi sebagai wadah. Sementara, pendekatan subjektif memandang organisasi sebagai kegiatan yang dilakukan orang-orang. Organisasi terdiri dari 
tindakantindakan, interaksi, dan transaksi yang melibatkan orang-orang. Berdasarkan pandangan objektif, organisasi berarti struktur; berdasarkan pandangan subjektif, organisasi berarti proses (Pace dan Faules, 2001).

Sutrisno (2010:2) menyebutkan bahwa budaya organisasi didefinisikan sebagai seperangkat sistem nilai-nilai, keyakinan keyakinan, asumsi-asumsi, atau norma-norma yang berlaku, disepakati, dan diikuti, oleh para anggota suatu organsisasi sebagai pedoman perilaku dan pemecahan masalah-masalah organsisasinya. Dalam penelitian tentang transformasi budaya perusahaan, pendekatan yang dipergunakan adalah pendekatan subjektif atau interpretif, di mana organisasi dipandang sebagai suatu proses yaitu proses perubahan budaya yang meliputi proses perubahan perilaku atau tindakan, proses interaksi, serta proses transaksi yang melibatkan seluruh anggota perusahaan.

\section{Budaya Organisasi}

Budaya didefinisikan oleh Zwell dalam Wibowo (2010) sebagai berikut:

"Budaya adalah cara hidup orang yang dipindahkan dari generasi ke generasi melalui berbagai proses pembelajaran untuk menciptakan cara hidup tertentu yang paling cocok dengan lingkungannya. Budaya merupakan pola asumsi dasar bersama yang dipelajari kelompok melalui pemecahan masalah adaptasi eksternal dan integrasi internal"

Dalam sebuah perusahaan penerapan budaya tersebut menjadi budaya organisasi. Budaya organisasi adalah sebuah sistem makna bersama yang dianut oleh para anggota yang membedakan suatu organisasi dari organisasiorganisasi lainnya. Sistem makna bersama ini adalah sekumpulan karakteristik kunci yang dijunjung tinggi oleh organisasi. Dengan kata lain, budaya adalah sebuah sistem makna bersama.

Schein dalam Moeljono (2003) menyatakan bahwa budaya korporat mengacu ke suatu sistem makna bersama yang dianut oleh anggota-anggota yang membedakan organisasi itu terhadap organisasi-organisasi lain. Vecchio memberi definisi budaya organisasi sebagai nilai-nilai dan normanorma bersama yang terdapat dalam suatu organisasi dan mengajarkan kepada pekerja yang datang. Adapun menurut Kreitner dan Kinicki budaya organisasi adalah nilai-nilai dan keyakinan bersama yang mendasari identitas perusahaan (Wibowo, 2010).

\section{Transformasi Budaya Organisasi}

Secara umum, budaya organisasi adalah sebuah sistem makna terhadap nilainilaiprimer yang dianut Bersama serta dihargai oleh organisasi. Hal ini menjadi pembeda antara satu organisasi dengan organisasi lainnya. Dengan demikian transformasi budaya organisasi adalah perubahan terhadap nilainilai primer yang dianut bersama dan dihargai organisasi, yang berfungsi menciptakan pembedaan yang jelas antara satu organisasi dengan organisasi lainnya.

\section{KERANGKA PEMIKIRAN}

Perusahaan biasanya dibentuk untuk mencapai tujuan tertentu. Keberhasilan perusahaan dalam mencapai tujuan tersebut sangat ditentukan oleh kinerja perusahaan yang sangat dipengaruhi oleh faktor eksternal dan faktor internal terutama oleh kinerja dan kesolidan para karyawan.

Adapun yang dimaksud dengan faktor eksternal dalam sebuah perusahaan adalah sesuatu yang berasal dari luar, meski begitu memiliki pengaruh yang sangat berar terhadap perusahaan tersebut. Dewasa ini, perusahaan sangat dipengaruhi oleh kecenderungan global yang semakin hari semakin kompetitif. Suatu perusahaan harus dapat merespon dengan baik pengaruh tersebut agar tidak berimbas buruk terhadap perusahaan. Sedangkan yang dimaksud dengan faktor internal dalam perusahaan yaitu terdiri dari sumber daya yang diperlukan untuk mewujudkan kinerja perusahaan dan nilai-nilai budaya yang dianut oleh segenap sumber daya manusianya.

Kedua faktor internal dan eksternal sangat menuntut perusahaan untukmenciptakan serta mempertahankan nilai-nilai budaya yang berlaku dan dianut sebagai pedoman dalam berperilaku bagi seluruh anggota perusahaan. 
Trujillo dan Pacanowsky dalam
Morissan mengemukakan sebuah teori bahwa budaya bukanlah sesuatu yang dimiliki oleh organisasi, budaya adalah sesuatu yang merupakan organisasi itu sendiri. Memahami individu sebagai suatu unit individu adalah lebih penting daripada melakukan generalisasi terhadap perilaku atau nilai-nilai organisasi secara keseluruhan.

Sementara Teori Konstruksi Sosial atas Realitas dalam salah satu asumsi dasarnya menyatakan bahwa: pemahaman terhadap realitas yang tersusun secara sosial membentuk banyak aspek penting dalam kehidupan, seperti aktivitas berpikir dan berperilaku (Koeswarno, 2008). Pemahaman yang baik oleh seluruh anggota perusahaan terhadap nilai budaya dapat membantu mereka dalam bertindak untuk membantu perusahaan mencapai tujuan serta membantu perusahaan dalam menciptakan identitas perusahaan, karena budaya merupakan cerminan dari tampilan perusahaan. "Budaya bervariasi dalam organisasi-organisasi yang berbeda, dan interpretasi tindakan dalam budaya ini juga beragam" (West dan Turner, 2007).

Selain sebagai identitas yang membedakan dari perusahaan lain, budaya perusahaan juga merupakan perekat antar karyawan, oleh sebab itu perusahaan harus memiliki budaya yang kuat, sehingga perusahaan dan karyawannya akan memiliki perilaku yang seiring sejalan serta memiliki keyakinan kolektif yang dapat meningkatkan kemampuan mereka bersaing di pasar. Teori Budaya Organisasi berasumsi bahwa: anggota organisasi menciptakan dan mempertahankan perasaan yang dimiliki bersama mengenai realitas organisasi (West dan Turner, 2007).

Dengan demikian, jelaslah bahwa nilai suatu budaya tidak serta merta hadir begitu saja, namun harus diciptakan serta dipertahankan dengan tujuan untuk diketahui dan dipahami oleh seluruh anggota perusahaan. Sebagai suatu proses, transformasi budaya perusahaan membutuhkan peran komunikasi, sosialisasi dan implementasi yang tentu saja melibatkan seluruh individu dan karwayan yang ada di perusahaan tersebut.

\section{METODE PENELITIAN}

Adapun paradigma yang dijadikan pedoman oleh peneliti dalam melakukan penelitian ini yaitu paradigma konstruktivisme dengan metode penelitian kualitatif dan pendekatan studi kasus. Pendekatan subjektif mengasumsikan bahwa pengetahuan bersifat interpretif. Perspektif interpretif merupakan pandangan subjektif mengenai realitas dan sifat manusia.

Perspektif ini berpendapat bahwa dunia sosial tidak eksis dalam pengertian yang konkret, tetapi dibangun oleh interaksi dan pengesahan secara konsensus para individu (Pace dan Faules, 2001). Perspektif interpretif (subjektif) melihat budaya organisasi sebagai proses pembentukan pemahaman yang membentuk realitas organisasi. Pendekatan subjektif memandang sebuah organisasi sebagai kegiatan yang dilakukan orang-orang yang bersifat aktif.

Yang menjadi subjek dalam penelitian ini yakni pimpinan PT. ABC Medium Dinamika, para karyawan perusaan tersebut dan orang-orang yang terkait dengan transformasi budaya perusahaan. Sementara pihak yang terkait langsung dalam proses transformasi budaya ini adalah General Manajer, Manajer, dan karyawan.

Objek penelitian ini adalah budaya perusahaan di PT. ABC Medium Dinamika. Penelitian ini menggunakan pendekatan kualitatif. Pendekatan kualitatif bersifat lentur dan terbuka dengan menekankan analisis induktif (empirico inductive) (Suprayogo dan Tabroni, 2001). Berpikir secara induktif, yaitu menangkap berbagai fakta atau fenomenafenomena sosial, melalui pengamatan di lapangan, kemudian menganalisisnya dan kemudian berupaya melakukan teorisasi berdasarkan apa yang diamati itu (Bungin, 2007).

Penelitian ini bersifat naturalistik deengan pendekatan interpretif. Sementara metode yang digunakan yaitu studi kasus. Alasan peneliti menggunakan metode ini dikarenakan peneliti ingin memahami fenomena yang terjadi yaitu transformasi budaya di PT ABC Medium Dinamika yang terjadi sejak tahun 2018. 
Adapun tekhnik pengumpulan data dalam penelitian ini menggunakan wawancara dengan semua pihak yang bersangkutan, melalui observasi di wilayah yang menjadi tempat penelitian, serta studi dokumentasi untuk menambah khazanah dan penguatan sumber secara beragam.

Dalam menentukan informan sebagai kunci utama penghasil data, peneliti menggunakan tekhnik purposive sampling (sampel bertujuan), dikarenakan pemilihan individu didasari atas berbagai pertimbangan. Adapun pertimbangan-pertimbangan tersebut kriterianya sebagai berikut:

1. Karyawan tetap, baik pimpinan maupun bawahan;

2. Terlibat langsung dalam proses transformasi budaya perusahaan;

3. Berperan aktif dalam proses transformasi budaya;

4. Menyatakan kesediaan untuk menjadi informan penelitian;

5. Memiliki kemampuan untuk mengekspresikan pengalaman dan pemahaman terhadap budaya perusahaan.

Adapun teknik analisis data yang dipergunakan dalam penelitian ini meliputi langkah-langkah sebagai berikut: pertama, reduksi data (data reduction), kedua, penyajian data (data display), dan ketiga, penarikan kesimpulan dan verifikasi (conclusion drawing and verification).

Sementara untuk mengatasi berbagai keraguan yang muncul terhadap hasil penelitian ini, penulis mencoba membangun mekanisme sistem pengujian keabsahan hasil penelitian dengan teknik pemeriksaan yang didasarkan atas sejumlah kriteria yaitu derajat kepercayaan (credibility), keteralihan (transferability),kebergantungan

(dependability), dan kepastian (confirmability).

\section{HASIL DAN PEMBAHASAN}

Dalam setiap organisasi tentu ada nilai dan norma yang dianut, sama halnya dengan PT ABC Medium Dinmika. Perusahaan ini menganut sebuah sistem, nilai, norma, kepercayaan, harapan, asumsi, persepsi yang mereka jadikan pedoman untuk membedakan dengan perusahaan lainnya. Perubahan budaya akan diperlukan jika nilai dan norma yang berlaku di dalam perusahaan tersebut sudah tidak lagi sesuai. Namun demikian, melakukan suatu transformasi budaya tidaklah mudah karena biasanya orang tidak mudah untuk melakukan suatu perubahan dan akan mempertahankan budaya lama yang sudah dianggap baik dan benar.

Menurut Thomas dan Inkson, melakukan perubahan budaya berarti melakukan perubahan pola pikir yang sudah tertanam dalam diri masing-masing. Budaya bukan hanya perilaku di permukaan, tetapi sangat dalam ditanamkan dalam diri kita masing-masing (Wibowo, 2010).

Para pemimpin dan karyawan beranggapan bahwa mengubah budaya sama halnya dengan mengubah nilai yang dianut Bersama. Mereka juga beranggapan bahwa mengubah budaya berarti mengubah pola perilaku ke pola pemikiran yang baru. Maka dari itu penulis menggambarkan pemahaman karyawan tentang budaya lama dan budaya baru perusahaan.

Hasil yang diperoleh menunjukkan bahwa pemahaman karyawan tentang budaya lama maupun budaya baru, mengandung nilai yang positif dan nilai yang negatif. Hal ini tidak terlepas dari aspek-aspek yang memengaruhi suatu proses komunikasi yakni komunikator, pesan, medium, komunikan, efek, dan feedback.

Dalam hal ini pemahaman para karyawan mengenai budaya lama dikelompokan menjadi tiga kategori, yaitu santai, kurang kompetitif, dan tidak client oriented. Perilaku santai yang dilakukan seorang pimpinan atau karyawan merupakan suatu pesan nonverbal yang dapat ditangkap oleh karyawan lain yang mempunyai efek terhadap karyawan tersebut.

Efek tersebut merupakan efek negatif karena memungkinkan para karyawan lain akan mengikuti perilaku tersebut. Budaya santai sudah menjadi stereotype untuk karyawan di PT. ABC. Hal ini juga tersirat dari ungkapan YD yang merupakan karyawan baru sebagai office boy di $\mathrm{ABC}$ ". disini santai banget mah mas kerjanya, tapi yah karyawan disini juga kan niru gaya kerja santai karena atasannya juga santai mas. Kalau lagi pusing 
karena banyak kerjaan nanti bisa turun dulu ke bawah ngopi sambil ngerokok" (wawancara dengan YD, 26 Desember 2018).

Pemahaman para karyawan tentang budaya lama dipengaruhi oleh pemikiran bahwa tidak adanya competitor terhadap perusahaan mereka, yang mana pada awal mula berdirinya PT ABC merupakan satu-satunya perusahaan agensi iklan di Indonesia.

$\mathrm{Hal}$ itu menyebabkan perusahaan kurang memperhatikan kualitas karyawan yang direkrut untuk menjadi karyawan di ABC. Salah seorang karyawan beranggapan bagaimana dulu karyawan itu tidak kompetitif sehingga tidak perlu kerja keras untuk mendapatkan konsumen.

Selain itu, budaya lama kurang bahkan cenderung tidak memperhatikan kepentingan konsumen atau klien. Informan yang merupakan salah satu karyawan dalam penelitian ini menyampaikan bahwa bahwa klien mau tidak mau harus mengeluarkan uang yang cukup besar dalam memasang iklan untuk kampanye merek mereka di medium sebab tidak adanya perusahaan lain yang dapat melakukan pekerjaan serupa:“... dulu klien datang ke kita mau gak mau harus datang bawa uang yang banyak biar bisa beriklan di medium. Jadi kita juga gampang milah-milah uang itu mau dialokasikan kemana ajah tinggal tutup mata juga bisa. Jadi klien mah percaya ajah sama kita, bagi mereka pokoknya penjualan mereka naik. Padahal kita bisa ajah bikin iklan merek mereka gak sesuai harapan mereka kan, dan karyawan juga respon nya kalo dapat brief dari klien biasa ajah."

Kurangnya pelayanan para karyawan terhadap konsumen atau klient merupakan bentuk dari kualitas karyawan yang kurang unggul serta kerap menyamaratakan antara karyawan yang satu dengan yang lainnya diakrenakan tidak adanya kompetisi. Kurangnya kompetisi menurut karyawan disebabkan karena perusaahaan yang berdiri sendiri dan tidak dikendalikan serta digandeng oleh pihak manapun baik oleh asing maupun lokal.

Dengan demikian semua pemimpin maupun karyawan erusahaan tidak berpikir bahwa klient lah yang semestinya menjadi prioritas utama. Namun tidak ada yang tau nasib seseorang akan seperti apa, lambat laun budaya itu terkikis seiring dengan berjalannya waktu, di mana perusahaan $\mathrm{ABC}$ bangkrut kemudian saham PT. ABC dibeli sepenuhnya oleh group Nava+, sebuah agensi periklanan multinasional. Kemudian secara keseluruhan perusahaan berubah dan kini $\mathrm{ABC}$ memiliki standar khusus dalam memilih karyawan dibawah kendali manajemen Nava+

Budaya lama yang mengangap bahwa klient bukanlah siapa-siapa dikemukakan pula oleh YR. Kurang keperdulian terhadap konsumen berakibat pada pelayanan yang kurang $\mathrm{ABCl}$ terhadap konsumen. “...di antaranya budaya juga harus ditanamkan karena kita mempunyai care terhadap konsumen kurang, pelayanan terhadap konsumen kurang" (wawancara dengan YR, 26 Januari 2012).

Anggapan bahwa konsumen yang membutuhkan perusahaan mengakibatkan karyawannya kurang menghadapi tantangan karena tidak ada pesaing, akibatnya secara otomatis tingkat persaingan pun tidak ada. Akibat dari tidak adanya persaingan adalah tidak adanya inovasi, karena karyawan beranggapan bahwa konsumenlah yang membutuhkan, tanpa inovasi pun konsumen pasti akan menggunakan produk atau menggunakan layanan jasa perusahaan.

Kekurangpedulian terhadap konsumen ini berakibat pada pelayanan yang kurang $\mathrm{ABCl}$ terhadap konsumen. Padahal, pelayanan terhadap konsumen merupakan hal utama dalam menumbuhkan kepercayaan konsumen. Bagaimanapun baiknya hasil suatu perusahaan apabila tidak diikuti dengan pelayanan yang $\mathrm{ABCl}$, sulit diharapkan untuk dapat diterima oleh konsumen; mengingat konsumen merupakan fokus utama dalam pembahasan mengenai kepuasan dan kualitas jasa.

Oleh karena itu, konsumen memegang peranan cukup penting dalam mengukur kepuasan, baik terhadap produk maupun terhadap pelayanan yang diberikan oleh perusahaan (Moeljono, 2003).

Adapun pemahaman karyawan mengenai budaya baru dikelompokan menjadi lima kategori yaitu, kekeluargaan, keteladanan pimpinan, fleksibelitas, dan client oriented. Kekeluargaan merupakan salah satu nilai 
budaya yang positif yang dianut pada budaya lama perusahaan, tidak ada negatifnya.

Sebenarnya PT ABC sendiri memiliki budaya kekeluargaan yang cukup baik, hal itu seperti yang dikemukakan oleh $\mathrm{AD}$ selaku karyawan sekaligus informan dalam penelitian ini “...kalau dulu kekeluargaannya bagus... yang saya inget budaya yang sangat kental di $A B C$ itu kekeluargaannya, tapi saya anggap itu bukan budaya yang tidak baik, sudah baik, hanya saja mungkin ada satu sisi menganggap kalau terlalu kekeluargaannya terlalu kental juga profesionalismenya sudah beda, nanti tidak akan bisa maksimal atau gimana" (wawancara dengan AD, 24 Desember 2018).

Pernyataan AD tadi diperkuat oleh pernyataan VT. VT merupakan karyawan yang sudah cukup lama bekerja di PT. ABC Medium yang beranggapan bahwa kekeluargaan merupakan sesuatu hal yang positif tidak ada negatifnya dan dulu $\mathrm{ABC}$ mempunyai budaya kekeluargaan yang baik, seperti yang diungkapkannya "... kalau dulu kekeluargaannya bagus" (wawancara dengan VT, 24 Desember 2018). Menurut Luthhans faktor utama yang menentukan kekuatan budaya organisasi adalah kebersamaan dan intensitas (Pabundu, 2006).

Rasa kebersamaan yang dirasakan dari budaya lama, dikarenakan PT ABC mengadakan kegiatan yang melibatkan seluruh karyawan dan pemimpin perusahaan. Menariknya, kegiatan tersebut dilakukan di satu tempat karena pada saat itu kantor $A B C$ terpusat di daerah Warung Buncit gedung perkantoran Shell sehingga komunikasi yang dilakukan antarsesama anggota perusahaan menjadi lebih intensif dan akrab. Kekeluargaan dan keteladanan pimpinan merupakan nilai budaya positif yang diciptakan dan perlu dipertahankan bersama oleh seluruh anggota perusahaan sehingga pemahaman mereka tentang nilai budaya perusahaan menjadi lebih baik, sesuai dengan salah satu asumsi dasar dari Teori Budaya Organisasi yang dikemukakan oleh Pacanowsky dan Trujillo yang menyatakan bahwa: "Anggota organisasi menciptakan dan mempertahankan perasaan yang dimiliki bersama mengenai realitas organisasi, yang berakibat pada pemahaman yang lebih baik mengenai nilai-nilai sebuah organisasi" (West danTurner, 2007).

Faktor berikutnya yang masih berkaitan dengan budaya lama dari PT ABC yaitu fleksibiitas. fleksibel di PT ABC yaitu adanya ketidakterikatan mengenai peraturan jam masuk kerja, jam waktu untuk istirahat, dan jam pulang.

Realitas yang diberlakukan oleh perusahaan hanyalah mengikuti peraturan yang telah ditetapkan pemerintah dimana karyawan atau pekerja minimal bekerja 8 jam per hari. Berkaitan dengan adanya regulasi tersebut PT. ABC tidak menetapkan jam masuk ataupun jam pulang kerja karyawannya, terlebih lagi untuk mengatur jam istirahat karyawan mereka.

Hal itu seperti yang diungkapkan oleh IK, ia merupakan salah seorang karyawan yang menajdi informan dalam penelitian ini, menurutnya jam masuk, jam pulang, dan jam istirahat di PT. ABC yang fleksibel sehingga dipercaya mampu menciptakan suasana kerja yang nyaman dan cocok dengan karyawan: “... dari dulu sampai sekarang ABC memang tidak pernah membatasi karyawan nya tentang peraturan jam masuk kerja, jam pulang kerja, ataupun jam istirahat. Ya... intinya kita mah kerja 8 jam sehari. Soal lembur disini tidak diwajibkan, lebih enak kita bilangnya disini loyalitas ajah dengan perusahaan. Kalau bicara tentang jam istirahat di ABC tidak ada ketentuan yang terikat kalau istirahat harus 45 menit sampai 60 menit seperti di perusahaan Jepang atau pabrik. Kita disini malah istirahat lebih dari 60 menit mas, yang terpenting bagi pimpinan kami mah mau istirahat lama juga gak apa-apa asal pekerjaan semua beres...", (wawancara dengan IK, 26 Desember 2018).

Dewasa ini, banyak kalangan milenial yang bergabung dengan industry pekerjaan. Kini perusahaan agensi pun mulai mengikuti perkembangan dengan zaman milenial saat ini begitupun dengan cara kerjanya. Perubahan yang terjadi biasnya dimulai dari aturan yang mulanya kaku bersifat fleksibel, mendekorasi ulang ruang kerja menjadi ruang kerja yang nyaman dan rileks layaknya di rumah dan santai.

Mengubah kebiasaan berpakaian yang formal menjadi lebih santai, dimana karyawan 
diperbolehkan mengenakan kaos dan celana jeans bahkan sepatu tidak mesti sepatu formal seperti pantofel.

Tidak berbeda dengan perusahaan pada umumnya, PT ABC Medium memiliki SOP yang mengatur cara kerja seluruh karyawan yang ada diperusahaan tersebut. Kini, PT ABC tidak hanya memfokuskan perusahaannya kepada bisnis semata, akan tetapi kepuasan dan kebutuhan para klient jauh lebih diutamakan. Cara kerja yang berfokus pada orientasi klien membuat PT. ABC Medium memperhatikan dan mempelajari dengan detail apa yang menjadi tujuan dan pencapaian dari klien mereka.

Dengan demikian, dalam proses kerjanya perintah dari atasan secara cepat langsung direspon dan dikerjakan oleh bawahannya. Berbicara mengenai pengolahan brief yang diterima dari klient akan diberikan ke bagian planning, selanjutnya masuk ke bagian pengolahan, kemudian masuk ke approvel plan.

Setelah melewati semua proses yang ada, maka data dimasukan ke bagian investment untuk dilakukan booking dan monitoring ke medium. Tibalah pada bagian finishing yaitu masuk ke bagian finance untuk membuat invoice dan iklan akan selesai pada saat kampanye.

\section{SIMPULAN}

Kinerja karyawan dalam sebuah perusahaan dipengaruhi oleh dua kebudayaan, yakni budaya lama dan budaya baru. Budaya lama pada perusahaan menyebabkan karyawan cenderung berperilaku negative, sebagai contoh bermalas-malasan misalnya, kurang kompetitif dan kurangnya client oriented. Sedangkan budaya baru dalam perusahaan cenderung mendorong para karyawan untuk berperilaku positif, sebagai contoh nilai budaya kekeluargaan, keteladanan pimpinan, fleksibelitas, dan client oriented.

Peneliti berharap selain penelitian dengan pendekatan studi kasus ini, para peneliti berikutnya dapat melakukan penelitian serupa dengan menggunakan pendekatan etnografi dalam memahami budaya perusahaan.
Komponen-komponen etnografi seperti genre, setting, urutan tindakan, kaidah interaksi, dan norma-norma interpretasi dapat terungkap dan tidak dibahas di studi kasus. Selain itu, peneliti berharap jika penelitian mengenai budaya perusahaan sebaiknya dilakukan dengan menggunakan paradigma kritis terutama berhubungan dengan kekuasaan dikarenakan perusahaan bukan tempat netral untuk pembentukan makna.

Dalam menerapkan budaya baru dalam sebuah perusahaan sebaiknya para pemimpin perusahaan lebih bersikap tegas dan teladan lagi sebab ia merupakan contoh atau role of model di mana para bawahan biasanya menjadikan para pemimpinnya sebagai contoh dalam bekerja.

Kerkenaan dengan penerapan transformasi tentu saja tidak mudah serta membutuhkan waktu cukup lama, maka dari itu diharapkan pihak perusahaan melakukan hal tersebut secara terus-menerus dan bersungguhsungguh agar perusahaan dapat bergerak dan mengikuti perkembangan zaman.

\section{DAFTAR PUSTAKA}

Buku:

Berger, Peter L, and Thomas Luckman. (1990). Tafsir Sosial atas Kenyataan. Terjemahan Hasan Basri dari The Social Contruction of Reality: A Treatise in the Sociology ofKnowledge. Jakarta: LP3ES.

Bungin, H.M. Burhan. (2007). Penelitian Kualitatif. Jakarta: Kencana.

Kuswarno, Engkus. (2008). Metode

Penelitian Komunikasi Etnografi

Komunikasi. Bandung: Widya

Padjadjaran.

Littlejohn, Stephen W. (2009). Teori

Komunikasi. Theories of Human

Communication. Jakarta: Salemba Humanika.

Mulyana, Deddy. (2001). Metodologi Penelitian Kualitatif. Bandung: 
Rosdakarya.

Moeljono, Djokosantoso. (2003). Budaya Korporat dan Keunggulan Korporasi. Jakarta: Gramedium.

Pace dan Faules. (2001). Komunikasi Organisasi. Strategi Meningkatkan Kinerja Perusahaan. Bandung: Remaja Karya.

Suprayogo, Imam dan Tobroni. (2001). Metodologi Penelitian Sosial-Agama. Bandung: Remadja Rosdakarya.

West, Richard and Lynn H. Turner. (2007). Introducing Communication Theory:
Analysis and Application. New York: Mc Graw Hill.

Wibowo. (2010). Budaya Organisasi. Sebuah Kebutuhan untuk Meningkatkan Kinerja Jangka Panjang. Jakarta: PT Rajagrafindo Persada.

\section{Sumber lainnya :}

Hasil Raker. (2008). Paparan Budaya Perusahaan.Subang.

Majalah Internal D File no 44, Desember 2010.

Majalah Internal D File no 47, Maret 2011. 